\title{
Studies on Schismatoglottideae (Araceae) of Borneo XXXII: Ooia paxilla, a new dwarf obligate rheophyte from Kalimantan Utara
}

\author{
Sin Yeng Wong ${ }^{\mathrm{a}}$ and Peter C. Boyce ${ }^{\mathrm{b} *}$ \\ ${ }^{a}$ Department of Plant Science \& Envionmental Ecology, Faculty of Resource Science \& Technology, Universiti Malaysia Sarawak, \\ Sarawak, Malaysia; ${ }^{b}$ School of Biological Sciences, Universiti Sains Malaysia, Pulau Pinang, Malaysia
}

(Received 22 August 2013; final version received 28 September 2013)

Ooia paxilla S.Y. Wong \& P.C. Boyce is described and illustrated as a new species of obligate rheophyte from shale waterfalls in Kalimantan Utara, Indonesian Borneo.

Keywords: Araceae; Schismatoglottideae; Ooia; Indonesian Borneo; shales

\section{Introduction}

Ooia S.Y. Wong \& P.C. Boyce is a recently segregated genus (from Piptospatha N.E.Br., see Wong and Boyce 2010) endemic to Borneo with until now two described species: the widespread and variable Ooia grabowskii (Engl.) S.Y. Wong \& P.C. Boyce, and the more locally restricted but also somewhat variable Ooia kinabaluensis (Bogner) S.Y. Wong \& P.C. Boyce. Both described Ooia species are rheophytes sensu van Steenis (1981, 1987), although neither is as strictly obligated to the rheophytic habitat as are other taxa of Schismatoglottideae, for example Aridarum Ridl. (Wong et al. 2012; Boyce and Wong 2013a, b). Ooia grabowskii usually occurs as the dominant species along sandy banks of forest streams, although it can also occur on exposed bare rocks along rivers, as for example at Kubah N.P. (Kuching Division, Sarawak, Malaysian Borneo), and Riam Pangar (Sanggau Ledo, Kalimantan Barat, Indonesian Borneo). In these habitats plants are frequently exposed to prolonged dry conditions at times of low water. Ooia kinabaluensis was long considered as endemic to Mount Kinabalu, Sabah, where it occurs at and above $1000 \mathrm{~m}$ altitude, but has now been found, too, on Gunung Retak, Brunei, at about $900 \mathrm{~m}$. Ooia kinabaluensis favours somewhat shaded rocky stream banks, and as with $O$. grabowskii experiences prolonged spells of dry conditions.

Over the past few years we have assembled a large collection of Ooia plants from numerous locations and have found that the apparent variability of at least $O$. grabowskii is probably an artefact of imprecise taxonomy. One collection in particular, originating from Malinau Regency, Kalimantan Utara, Indonesian Borneo, has long puzzled us in remaining dwarf, with the petioles and leaf blades spreading (not arching-erect) despite clearly growing well. This collection has recently flowered, revealing itself to be a clearly distinct, undescribed, species, which we describe here.
Ooia paxilla P.C. Boyce \& S.Y. Wong, sp. nov.

Diagnosis

From O. grabowskii, O. paxilla is differentiated by having only a single row of subpistillar staminodes (about five rows of staminodes, with the staminodial zone almost equalling the pistillate zone in length), and by the pink stigmas that are smaller than the width of the ovary (versus stigmas pale greyish and wider than the ovary). Ooia paxil$l a$ is distinguished from $O$. kinabaluensis by the dense (not lax) pistillate flowers with pink (not orange) stigmas, and by the staminate flower zone exceeding (not equalling) the width of the pistillate zone (Figure 2). Ooia paxilla may be differentiated from both $O$. grabowskii and $O$. kinabaluensis by the spreading (not arching erect) inflorescences and leaves, and by its obligation to shales.

Type: Indonesian Borneo, Kalimantan Utara, Malinau Regency, Malinau Selatan District, Sembakung, $80 \mathrm{~km}$ southwest of Malinau, Tempat Wisata Riam Loreh, $3 \mathrm{kn}$ north of Long Loreh village, $3^{\circ} 9^{\prime} 24^{\prime \prime} \mathrm{N}, 116^{\circ} 29^{\prime} 36^{\prime \prime} \mathrm{E}$, 3 May 2012, K. Nakamoto AR-3926 (holo BO!; iso SAR [spirit]) (Figure 1).

\section{Description}

Rheophytic herb c. $10 \mathrm{~cm}$ tall. Stem c.4-8 cm long, somewhat elongate with internodes to $1 \mathrm{~cm}$ long, $0.6-1.5 \mathrm{~cm}$ diameter, roots strong, $2.5-3 \mathrm{~mm}$ thick, active tips with a conspicuous gel "cap". Leaves about 10 together; petiole brownish purple, 3-12 cm long, c. $3 \mathrm{~mm}$ diameter, adaxially very shallowly canaliculate, sheathing only at the very bottom of the base, the wings extended into a narrowly triangular ligular portion 2-3 cm long; blade elliptic to ellipticoblong, $5-11 \mathrm{~cm}$ long by $2-3.5 \mathrm{~cm}$ wide, bright mid-green adaxially, abaxially paler, the base cuneate, the apex acute and apiculate for $2-3 \mathrm{~mm}$; midrib prominent abaxially, adaxially somewhat impressed, sometimes abaxially purple,

*Corresponding author. Email: phymatarum@gmail.com 


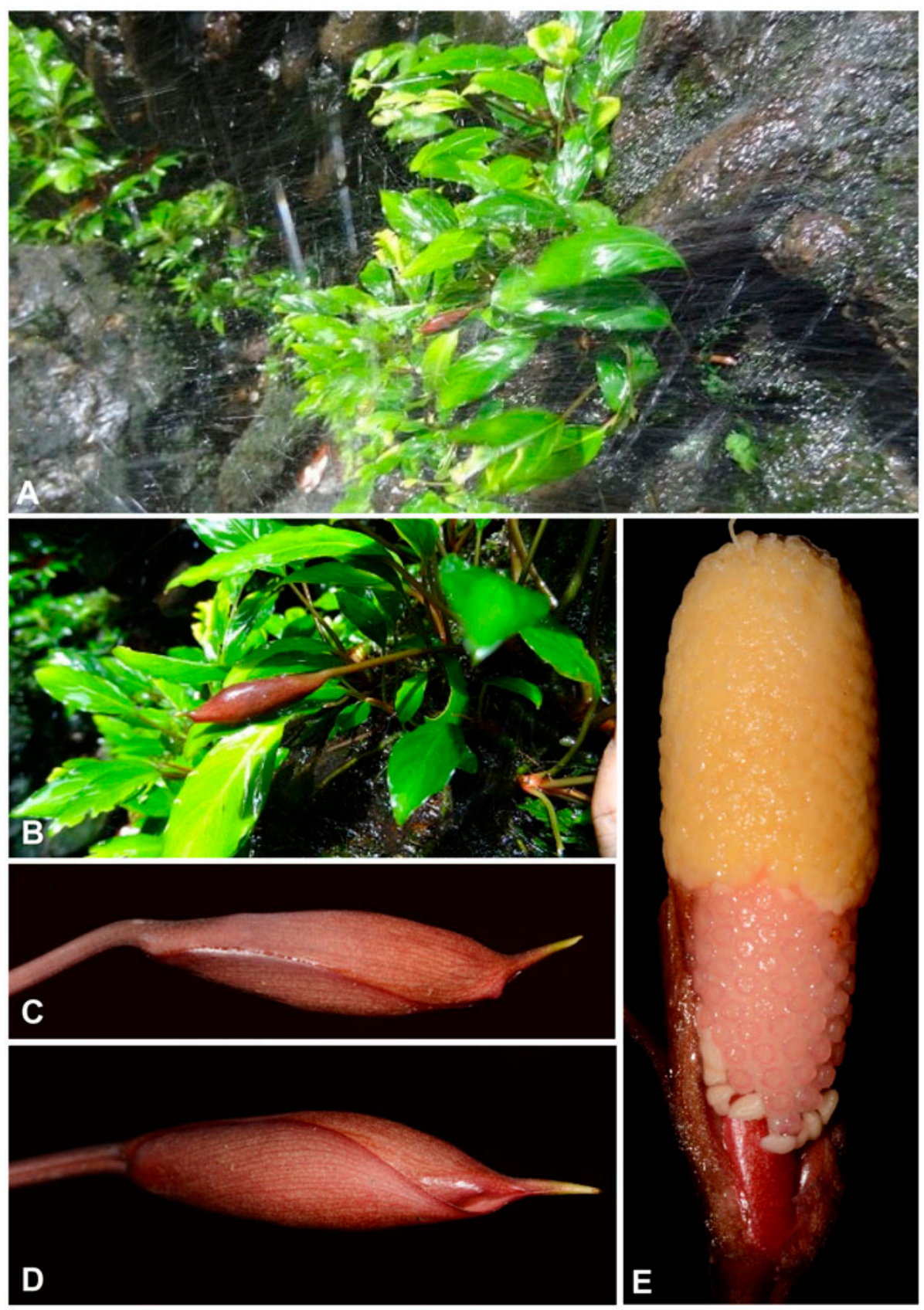

Figure 1. (A-E) Ooia paxilla S.Y. Wong \& P.C. Boyce. (A, B) Plants in Type habitat on constantly water-washed shales. (C, D) Inflorescence at staminate anthesis, lateral (C) and ventral (D), views. Note that the spathe limb hardly opens. (E). Spadix (spathe artificially removed) at staminate anthesis. Note the distinctive subpistillar staminodes. All from K. Nakamoto AR-3926. Photo credits: A, B (C) K. Nakamoto, used with permission; C-E (C) Peter C. Boyce.

with 8-11 primary lateral veins on each side, more or less regularly alternating with lesser interprimaries and diverging at c. $45-60^{\circ}$; secondary venation abaxially fine, adaxially obscure; tertiary venation obscure. Inflorescences two or three together alternating with prophylls; peduncle pendent in nature (laying flat on the ground in cultivation) $8-12 \mathrm{~cm}$ long, c. $2 \mathrm{~mm}$ diameter, reddish brown. Spathe ovoid-subcylindric, c. $2.5 \mathrm{~cm}$ long, $1 \mathrm{~cm}$ diameter, apically beaked for c. $4 \mathrm{~mm}$, persistent, glossy reddish brown, orthotropous on a pendent peduncle at anthesis. Spadix 1.8$2.5 \mathrm{~cm}$ long, subcylindric to slightly clavate, shortly stipitate with the stipe adnate to the spathe, deep glossy reddish; pistillate flower zone $6-7.5 \mathrm{~mm}$ long, c. $4 \mathrm{~mm}$ diameter; ovary ovoid c.1.2 $\mathrm{mm}$ diameter, pink; stigma sessile, discoid, narrower than ovary, pink; staminodes confined to a single row below the pistillate flower zone; staminodes stipitate, about as tall as the pistils, c. $1.2 \mathrm{~mm}$ diameter, irregularly polygonal, flat-topped, glossy white; sterile interstice absent; staminate flower zone 9-11 mm long, 5.5$6.5 \mathrm{~mm}$ diameter; bullet-shaped, apically obtuse, fertile to apex; stamens crowded, arranged in pairs, truncate, flattopped, more or less rectangular from above, c.1.1 mm across, minutely hairy on the upper surface, pale orange; thecae opening through apical pores. Fruiting spathe 

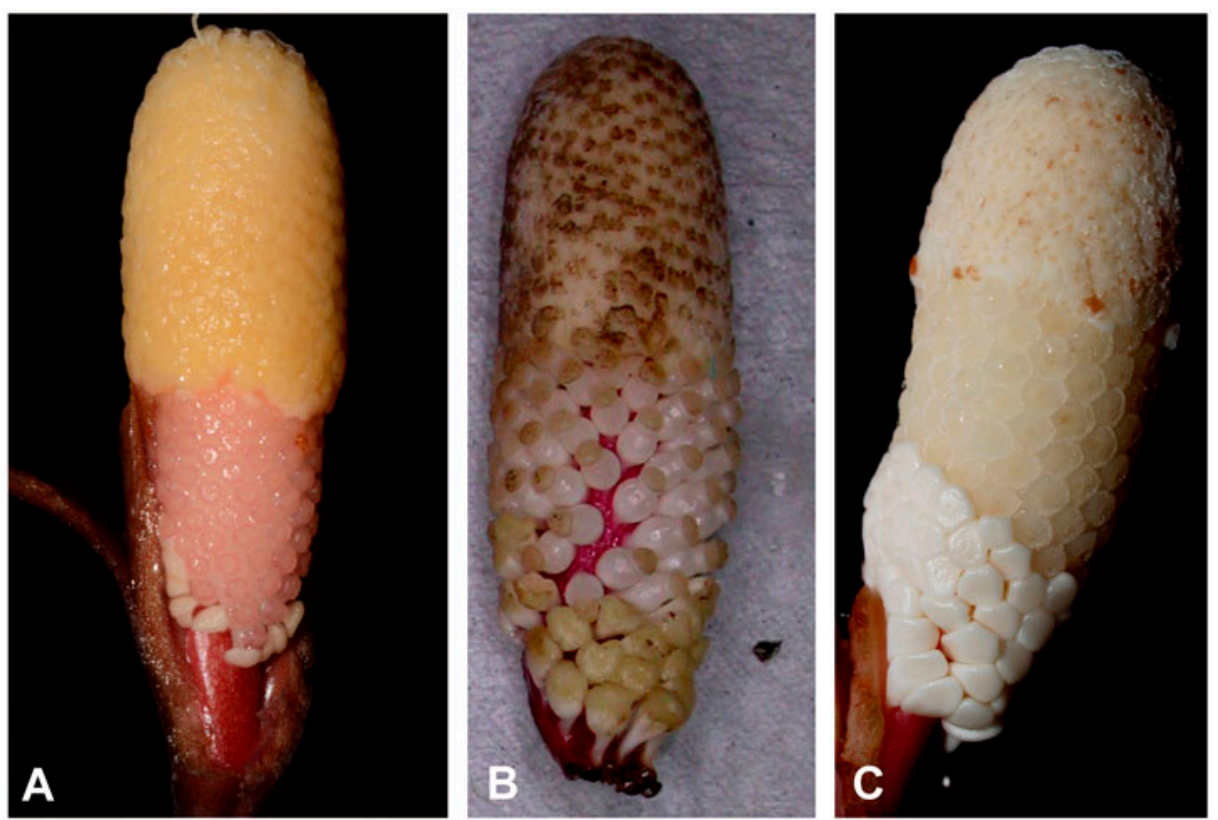

Figure 2. (A) Ooia paxilla S.Y. Wong \& P.C. Boyce. (B) Ooia kinabaluensis (Bogner) S.Y. Wong \& P.C. Boyce. (C) Ooia grabowskii (Engl.) S.Y. Wong \& P.C. Boyce. (A) from K. Nakamoto AR-3926; (B) from M. Lo AR-4087; (C) P.C. Boyce et al. AR-2118. Photo credits: (C) Peter C. Boyce.

ovoid-subcylindric, deep reddish brown, pendent, infructescence not observed. Figure 2

\section{Distribution}

Ooia paxilla is so far known only from the type locality in Indonesian Borneo, Kalimantan Utara.

\section{Ecology}

Ooia paxilla grows on constantly river-splashed shale river boulders and on permanent waterfalls under wet lower hill forest at an altitude of about $200 \mathrm{~m}$.

\section{Etymology}

From the Latin, paxillus (masc.), a peg or small stake, in reference to the highly distinctive sub-pistillar staminodes which are diagnostic for this species.

\section{Notes}

Ooia paxilla is a remarkable species in occurring under constant water flow (Figure 1A, B). It is speculated that the entirely pendent inflorescences are adapted to this ecology. Ripe infructescences have not been observed, and so the spathe senescence mechanics and fruit/seed dispersal are unknown. Given the very different ecology of $O$. paxilla compared with the other described species, it seems highly probable that a different dispersal mechanism is employed; observations are required.

\section{Key to genus Ooia}

1a. Subpistillar staminodes about five rows, with the staminodial zone almost equalling the pistillate zone in length; stigmas pale greyish, wider than the ovary. Widespread on Borneo on a variety of substrates.

Ooia grabowskii

1b. Subpistillar staminodes in one row; stigmas pink or orange, narrower than ovary .......................2

2a. Pistils dense; stigmas pink; staminate flower zone exceeding the width of the pistillate zone. Shales. Riam Loreh, Kalimantan Utara

Ooia paxilla

2a. Pistils lax; stigmas orange; staminate flower zone equalling the width of the pistillate zone. Granite. Gunung Kinabalu (Sabah) and Gunung Retak (Brunei)

Ooia kinabaluensis

\section{References}

Boyce, PC and Wong, SY. 2013b. Studies on Schismatoglottideae (Araceae) of Borneo XXII: The enigmatic Aridarum montanum Ridl. refound. Gard Bull Singapore. 65(1): 1-5.

Boyce PC, Wong SY 2013a. Studies on Schismatoglottideae (Araceae) of Borneo XXVII - New species of Aridarum, and notes on the Aridarum Rostratum Complex. Willdenowia. 43:91-99.

Van Steenis CGGJ. 1981. Rheophytes of the world: an account of the flood-resistant flowering plants and ferns and the theory of autonomous evolution. Alpena aan den Rijn. and Rockville: Sijthoff \& Noordhoff.

Van Steenis CGGJ 1987. Rheophytes of the world. Supplement. Allertonia. 4 (Supplement):267-330.

Wong SY, Boyce PC 2010. Studies on Schismatoglottideae (Araceae) of Borneo XI: Ooia, a new genus and a new generic delimitation of Piptospatha. Bot Stud (Teipei). 51:543-552.

Wong SY, Boyce PC, Low SL 2012. Studies on Schismatoglottideae (Araceae) of Borneo XXIV - Two new species of Aridarum from Kalimantan, and notes on the Aridarum Burttii Complex. Willdenowia. 42:261-268. 